\title{
DESAIN LEMBAR KERJA PESERTA DIDIK BERBASIS PROBLEM BASED LEARNING UNTUK MENINGKATKAN SELF-EFFICACY PESERTA DIDIK
}

\author{
Ade Silvia Wahyuni ${ }^{\mathbf{1}^{*}}$ dan Miterianifa ${ }^{\mathbf{1}}$ \\ ${ }^{7}$ Program Studi Pendidikan Kimia, Fakultas Tarbiyah dan Keguruan, \\ Universtas Islam Negeri Sultan Syarif Kasim Riau, Jl. H. R. Soebrantas No. 155 Km 15 \\ Simpang Baru Panam, Pekanbaru 28293, Indonesia \\ "E-mail: adesilviawahyuni@gmail.com
}

\begin{abstract}
ABSTRAK
Penelitian ini bertujuan untuk mendesain Lembar Kerja Peserta Didik berbasis Problem Based Learning untuk meningkatkan self efficacy peserta didik pada materi kelarutan dan hasil kali kelarutan yang valid berdasarkan validitas ahli materi, ahli media, praktikalitas guru dan respon peserta didik. Metode penelitian yang digunakan adalah Research and Development $(R \& D)$ dengan model pengembangan Borg and Gall. Penelitian ini dilaksanakan di MA Darul Hikmah Pekanbaru terhadap peserta didik kelas XI sains. LKPD dikatakan layak jika memenuhi aspek valid dan praktis. Kevalidan dilihat dari hasil validasi dengan menggunakan lembar validasi. Berdasarkan analisis data diperoleh hasil validasi ahli materi secara keseluruhan sebesar $94 \%$ dengan kriteria sangat valid. Validasi ahli media secara keseluruhan sebesar $98 \%$ dengan kategori sangat valid. Uji praktikalitas guru dilakukan pada 3 orang guru dan mendapatkan hasil sebesar $87 \%$ dengan kategori sangat praktis. Respon peserta didik didapat dari 15 orang peserta didik dilihat dari hasil angket sebesar $81 \%$ dengan kategori sangat praktis. Peningkatan self efficacy peserta didik dapat diketahui melalui perhitungan $\mathrm{N}$-gain berdasarkan hasil pretest dan posttest. Rata-rata $N$-gain yang diperoleh yaitu 0,1378 dengan kategori rendah. Selain itu Peningkatan self efficacy peserta didik dapat dilihat dari angket yaitu hasil perhitungan skor menunjukkan 40\% peserta didik mempunyai self efficacy yang sangat tinggi, $47 \%$ peserta didik pada kriteria tinggi, dan $13 \%$ pada kriteria cukup tinggi.
\end{abstract}

Kata kunci: lembar kerja peserta didik, problem based learning, self efficacy

\begin{abstract}
This research aimed at designing problem-based student worksheet that was valid based on validity of material and media experts, practicality of teacher and response of students in increasing student self efficacy on Solubility and Solubility Product concept. The method used was Research and Development (R\&D) with Borg and Gall development model. It was implemented at the eleventh grade students of Science Islamic Senior High of Darul Hikmah Pekanbaru. Student worksheet was considered appropriate when it meet validity and reliability aspects. Validity was seen from validity result of using validation sheet. Based on data analysis obtained validation result of material experts was $94 \%$ that was on very valid criterion. The validation result of media experts was $98 \%$ that was on very valid criterion. Practicality test was done to 3 teachers and it was obtained $87 \%$ result that it was on very practical category. Response of 15 students that was seen from questionnaire result was $81 \%$ and it was on very practical category. The increase of student self efficacy could be known through the calculation of N-gain
\end{abstract}


based on pretest and posttest results. $N$-gain mean was 0.1378 and it was on low category. Moreover, the increase of student self efficacy could be known from questionnaire, it was obtained that $40 \%$ students had very high criterion of self efficacy, $47 \%$ students had high criterion, and $13 \%$ students had adequate criterion.

Keywords: student workbook, Problem Based Learning, self efficacy

DOI: https://doi.org/10.15575/jtk.v4i1.4240

\section{PENDAHULUAN}

Kebijakan pemerintah pada saat ini salah satunya adalah penyusunan kurikulum baru yaitu Kurikulum 2013. Melalui perubahan kurikulum ini pemerintah mengharapkan adanya revolusi mental terhadap peserta didik (Sari dkk., 2016). Salah satu cara untuk merevolusi mental anak bangsa adalah dengan memberikan pendidikan karakter. Pendidikan karakter saat ini menjadi hal yang penting untuk ditingkatkan. Pendidikan karakter berfungsi untuk mengembangkan kemampuan dan membentuk karakter agar dapat mencerdaskan kehidupan bangsa. Di antara banyaknya karakter yang ingin ditanamkan pada diri peserta didik, karakter percaya pada kemampuan diri sendiri adalah salah satunya (Ikhasaum, 2016). Karakter percaya pada kemampuan diri sendiri disebut juga dengan self efficacy.

Self efficacy berkaitan dengan keyakinan seseorang terhadap kemampuan yang dimilikinya sehingga ia mampu menyelesaikan pekerjaan dan tugas yang diembannya. Pikiran individu terhadap self-efficacy akan menentukan seberapa besar usaha yang akan dicurahkan dan seberapa lama individu akan tetap bertahan dalam menghadapi hambatan atau pengalaman yang tidak menyenangkan selama proses pembelajaran. Peserta didik dengan efikasi diri yang rendah dalam mengerjakan tugas yang diberikan akan cenderung menghindari tugas atau cenderung untuk tidak mengerjakan tugas yang diberikan dan lebih memilih untuk mencontek tugas milik temannya. Peserta didik menganggap tugas yang diberikan sulit dan tak mampu diselesaikan. Sebaliknya peserta didik yang memiliki efikasi diri yang tinggi akan terus berusaha menyelesaikan tugas seberapapun sulitnya tugas tersebut walaupun peserta didik tersebut belum mengetahui apakah tugas yang dibuatnya benar atau salah (Sunaryo, 2017).

Peserta didik tidak dapat terhindar dari tugastugas yang diberikan oleh guru pada mata pelajaran kimia. Peserta didik dituntut mampu menyelesaikan semua tugas dengan baik sebagai refleksi dan evaluasi dari penguasaan peserta didik terhadap materi yang telah diajarkan. Salah satu materi pada pembelajaran kimia yang sering dianggap sulit oleh peserta didik kelas XI SMA adalah kelarutan dan hasil kali kelarutan. Materi kelarutan dan hasil kali kelarutan atau juga sering disebut $K_{s p}$ (Konstanta of Solubility Product) merupakan materi yang tidak hanya memerlukan pemahaman yang mendalam, tapi juga sarat dengan hitungan sehingga kemampuan matematis dan analisis sangat diperlukan untuk memecahkan permasalahan yang ada pada materi tersebut (Diba, 2017). Dengan ditingkatkannya self efficacy, peserta didik akan mampu memahami materi kelarutan dan hasil kali kelarutan dengan baik serta memiliki kepercayaan diri yang tinggi dalam mengerjakan setiap tugas yang diberikan. Peningkatan self efficacy peserta didik dapat dilakukan menggunakan model 
Desain Lembar Kerja Peserta Didik Berbasis Problem Based Learning untuk Meningkatkan Self Efficacy Peserta Didik

pembelajaran Problem Based Learning (PBL). Penggunaan model pembelajaran $P B L$ adalah upaya yang tepat untuk mengakomodasi peningkatan self efficacy peserta didik. Pembelajaran dengan model PBL yang memberikan persoalan dalam bentuk masalah autentik, dapat menyusun pengetahuan peserta didik, menumbuhkembangkan keterampilan yang lebih tinggi, memandirikan peserta didik dan meningkatkan kepercayaan diri sendiri (Aprilia, 2015). Peningkatan self efficacy dengan menggunakan model pembelajaran $P B L$ dapat dilakukan dengan mengembangkan bahan ajar sebagai sumber belajar peserta didik. Salah satu bahan ajar yang sering dikembangkan adalah LKPD (Lembar Kerja Peserta Didik). LKPD dapat mengarahkan peserta didik untuk bekerja secara mandiri. LKPD dapat dibuat sesuai dengan metode atau model pembelajaran yang digunakan dan tujuan pembelajaran yang diinginkan. LKPD yang dapat digunakan oleh peserta didik secara optimal adalah lembar kerja peserta didik yang berkualitas dan mudah dipahami peserta didik. Persyaratan LKPD yang berkualitas ialah harus memenuhi tiga syarat yaitu syarat didaktik, syarat konstruksi dan syarat teknis.

Hasil studi awal di MA Darul Hikmah Pekanbaru menunjukkan bahwa self efficacy peserta didik masih rendah. Hal ini dibuktikan dengan kurangnya minat peserta didik mengerjakan latihan dan tugas yang diberikan. Sebagian peserta didik cenderung untuk melihat tugas milik temannya yang sudah selesai mengerjakan. Selain itu pada saat proses pembelajaran kimia, guru belum menggunakan LKS atau LKPD. Guru menggunakan buku cetak sebagai alat penunjang dalam proses pembelajaran. Tetapi penggunaan buku cetak dalam proses pembelajaran belum sepenuhnya efektif. Hal ini karena menurut sebagian peserta didik buku cetak yang digunakan masih sulit untuk dimengerti dan bahasa buku yang digunakan terlalu tinggi. Selain itu buku cetak yang digunakan belum sepenuhnya mengaktifkan peserta didik selama proses pembelajaran, hal ini karena kurangnya latihan-latihan soal yang terdapat di dalam buku cetak sehingga proses pembelajaran yang student center belum dapat diterapkan sepenuhnya.

LKPD yang selama ini digunakan belum dapat memfasilitasi peserta didik untuk mengembangkan kemampuan pemecahan masalah dan menumbuhkan self efficacy peserta didik. Oleh karena itu diperlukan LKPD yang dapat meningkatkan kemampuan pemecahan masalah dan self efficacy peserta didik. Karena self-efficacy membantu seseorang dalam menentukan pilihan, usaha mereka untuk maju, kegigihan dan ketekunan yang mereka tunjukkan dalam menghadapi kesulitan, dan derajat kecemasan atau ketenangan yang mereka alami saat mereka mempertahankan tugas-tugas yang mencakupi kehidupan mereka (Sunaryo, 2017). Menurut Ormrod yang dikutip oleh Hairida mengemukakan bahwa self efficacy diperlukan peserta didik dalam menghadapi tuntutan zaman yang semakin maju. Peserta didik yang memiliki self efficacy yang tinggi akan mampu untuk mencapai berbagai tujuan di dalam hidupnya. Seseorang akan lebih mungkin terlibat dalam perilaku tertentu ketika mereka yakin bahwa mereka akan mampu menjalankan perilaku tersebut dengan sukses, yaitu ketika mereka memiliki self efficacy tinggi. Dengan demikian, self efficacy peserta didik perlu mendapatkan perhatian guru agar potensi peserta didik dapat dioptimalkan. Dalam konteks pendidikan, jika peserta didik memiliki self efficacy maka ia akan termotivasi agar berhasil mencapai tujuan pembelajaran dan dapat bertahan ketika menghadapi kesulitan (tugas), karena self efficacy mempengaruhi bagaimana orang berpikir, merasa, memotivasi diri, dan 
Desain Lembar Kerja Peserta Didik Berbasis Problem Based Learning untuk Meningkatkan Self Efficacy Peserta Didik

bertindak. Hal ini sejalan dengan pendapat dari Schunk bahwa peserta didik yang memiliki self efficacy terhadap pembelajaran, cenderung memiliki cara-cara untuk membuat dirinya dapat keluar dari hambatan atau gangguan dalam belajar, sehingga menjadi efektif dalam belajar (Hairida, 2017).

Peningkatan kemampuan pemecahan masalah peserta didik dapat dilakukan dengan menerapkan model pembelajaran Problem Based Learning. Problem Based Learning mendorong peserta didik untuk menemukan pemecahan masalah yang diberikan sehingga dapat membantu untuk meningkatkan kemampuan diri peserta didik. Penerapan Problem Based Learning merupakan suatu pendekatan pengajaran yang mempelajari masalah dunia nyata sebagai konteks bagi peserta didik untuk memperoleh pengetahuan serta konsep yang esensi dari mata pelajaran. Model Problem Based Learning adalah model pembelajaran yang merangsang peserta didik untuk berpikir menyelesaikan permasalahan kontekstual. Melalui model Problem Based Learning, peserta didik menyusun pengetahuan dengan membangun penalaran sehingga diharapkan dapat memecahkan masalah dengan beragam alternatif solusi serta mengidentifikasi permasalahan yang ada (Hardiyanti dkk., 2017).

Perlu adanya suatu usaha untuk mengembangkan bahan ajar yang inovatif salah satunya dengan mengembangkan LKPD berbasis Problem Based Learning yang digunakan dalam pembelajaran kimia agar membantu pembelajaran menjadi lebih layak dan efektif. LKPD berbasis Problem Based Learning ini dapat digunakan secara mandiri dengan bantuan atau tanpa bantuan guru. Pembelajaran dengan LKPD memungkinkan peserta didik untuk belajar lebih cepat menyelesaikan satu atau lebih permasalahan yang diberikan. Dengan demikian LKPD berbasis Problem Based Learning ini dapat mendorong peserta didik untuk meningkatkan self efficacy. Dengan LKPD ini peserta didik merasa yakin dengan kemampuan yang dimilikinya. Hal ini disebabkan karena keyakinan terhadap kemampuan sendiri merupakan modal utama dalam setiap hal. Seperti dalam dunia pendidikan, self efficacy dapat memberikan pengaruh yang positif baik bagi peserta didik maupun dalam prestasinya.

Berdasarkan pemaparan di atas penulis melakukan penelitian dengan mendesain lembar kerja peserta didik berbasis Problem Based Learning untuk meningkatkan self efficacy peserta didik.

\section{METODE PENELITIAN}

Jenis penelitian ini digolongkan ke dalam penelitian pengembangan (Research and Development) dengan menggunakan model pengembangan Borg and Gall namun hanya sampai pada tahap ke lima yaitu revisi uji coba. Penelitian ini menghasilkan LKPD yang akan divalidasi dan diujicobakan terbatas. Penelitian ini dilakukan di MA Darul Hikmah Pekanbaru dengan subjek penelitian sebanyak 15 orang peserta didik kelas XI Sains.

Instrumen penelitian yang digunakan adalah angket validasi ahli materi, angket validasi ahli media, angket kepraktisan guru, angket respon peserta didik, dan angket self efficacy peserta didik. Uji validasi digunakan untuk mengetahui hasil validasi LKPD yang dinilai oleh empat orang dosen pendidikan kimia, di mana dua orang merupakan ahli media, dan dua orang lagi merupakan ahli materi. Praktikalitas guru dan respon peserta didik digunakan untuk melihat bagaimana tanggapan guru dan peserta didik terhadap kemenarikan dan kemudahan LKPD yang didesain. Data diperoleh dari hasil angket validasi, kepraktisan dan respon peserta didik. 
Desain Lembar Kerja Peserta Didik Berbasis Problem Based Learning untuk Meningkatkan Self Efficacy Peserta Didik

Analisis data hasil validasi dan kepraktisan dilakukan terhadap setiap aspek dalam lembar angket. Skor data hasil angket diperoleh berdasarkan rating scale dengan kisaran skor 1 sampai 5. Kriteria penskoran ialah skor 1 (tidak baik), 2 (kurang baik), 3 (cukup baik), 4 (baik), dan 5 (sangat baik). Skor dikonversikan dengan menggunakan persamaan;

$$
\text { Persentase }=\frac{\text { skor yang diperoleh }}{\text { skor maksimal }} \times 100 \%
$$

Adapun kriteria interpretasi nilai dari angket validasi, praktikalitas guru, dan respon peserta didik terhadap LKPD dapat dilihat pada Tabel 1.

Tabel 1. Kriteria hasil angket validasi terhadap LKPD (Riduwan, 2017)

\begin{tabular}{clc}
\hline No. & Persentase (\%) & Kriteria \\
\hline 1. & $80 \leq$ Nilai $\leq 100$ & Sangat valid \\
2. & $60 \leq$ Nilai $<80$ & Valid \\
3. & $40 \leq$ Nilai $<60$ & Cukup valid \\
4. & $20 \leq$ Nilai $<40$ & Kurang valid \\
5. & $0 \leq$ Nilai $<20$ & Tidak valid \\
\hline
\end{tabular}

Tabel 2. Kriteria hasil angket praktikalitas guru dan respon peserta didik terhadap LKPD

\begin{tabular}{cll}
\hline No. & $\begin{array}{c}\text { Persentasi } \\
(\%)\end{array}$ & Kriteria \\
\hline 1. & $\begin{array}{l}80 \leq \text { Nilai } \leq \\
100\end{array}$ & Sangat praktis \\
2. & $\begin{array}{l}60 \leq \text { Nilai }< \\
80\end{array}$ & Praktis \\
3. & $\begin{array}{l}40 \leq \text { Nilai }< \\
60\end{array}$ & Cukup praktis \\
4. & $\begin{array}{l}20 \leq \text { Nilai }< \\
40\end{array}$ & Kurang praktis \\
5. & $\begin{array}{l}0 \leq \text { Nilai }< \\
20\end{array}$ & Tidak praktis \\
\hline
\end{tabular}

Angket self efficacy digunakan untuk mengetahui peningkatan self efficacy peserta didik. Angket self efficacy ini diberikan di awal pembelajaran sebelum menggunakan LKPD dan diakhir pembelajaran setelah menggunakan LKPD yang didesain. Untuk mengetahui peningkatan self efficacy secara keseluruhan digunakan gain score. Skor yang diperoleh dari gain score akan diinterpretasikan dengan kriteria $N-g \geq 0,7$ (tinggi); $0,7>N-g \geq 0,3$ (sedang); dan $N-g<0,3$ (rendah) (Agustini dkk., 2017).

\section{HASIL DAN PEMBAHASAN}

Bahan ajar yang didesain dalam penelitian ini berupa Lembar Kerja Peserta Didik berbasis Problem Based Learning untuk meningkatkan self efficacy peserta didik pada materi kelarutan dan hasil kali kelarutan. LKPD ini didesain oleh penulis agar dapat menjadi bahan ajar yang dapat membantu guru dalam proses pembelajaran dan sebagai salah satu sumber belajar bagi peserta didik baik di kelas maupun di rumah.

Lembar Kerja Peserta Didik berbasis Problem Based Learning untuk meningkatkan self efficacy peserta didik dikembangkan dengan menggunakan prosedur pengembangan menurut Borg and Gall yang disederhanakan sesuai kebutuhan penelitian menjadi lima tahap. Tahap awal dalam proses pengembangan Borg and Gall adalah penelitian dan pengumpulan data yaitu melakukan survey lapangan untuk mengetahui kebutuhan peserta didik dan studi pustaka untuk mengkaji literatur dan jurnal sehingga didapatkan alasan perlunya pengembangan LKPD berbasis PBL untuk meningkatkan self efficacy peserta didik.

LKPD menjadi salah satu bagian penting dalam proses pembelajaran. Hal ini karena LKPD dapat mengaktifkan peserta didik untuk belajar secara mandiri. Dengan adanya LKPD diharapkan peserta didik mampu memahami konsep yang ada sebelum pembelajaran dimulai, sehingga ketika proses pembelajaran 
peserta didik tidak lagi bergantung pada penjelasan guru. Selain itu dengan adanya LKPD diharapkan peserta didik akan terlatih untuk mengerjakan setiap latihan yang ada. Dengan demikian pembelajaran yang student centered dapat terwujud. LKPD perlu dikembangkan oleh guru mata pelajaran. Hal ini agar LKPD yang digunakan sesuai dengan karakteristik peserta didik dan sesuai dengan keadaan lingkungan sekolah. Berdasarkan jurnal penelitian yang ditulis oleh Evendy mengatakan bahwa bahan ajar perlu dikembangkan dalam pembelajaran. Hal ini karena bahan ajar yang digunakan harus sesuai dengan tuntutan kurikulum yang berlaku, karakteristik peserta didik, dan tuntutan dalam pemecahan masalah. Berdasarkan analisis kebutuhan bahan ajar, diketahui bahwa LKPD merupakan salah satu bahan ajar yang sering dipakai dan dibutuhkan dalam pembelajaran. Lembar Kerja Peserta Didik merupakan suatu bahan ajar cetak berupa lembaran yang berisi materi dan tugas yang ada petunjuk pembelajaran dan langkah-langkah untuk menyelesaikan tugas. LKPD dapat berupa panduan untuk latihan pengembangan aspek kognitif maupun panduan untuk pengembangan semua aspek pembelajaran dalam bentuk panduan eksperimen dan demonstrasi (Evendy dkk., 2018).

Penggunaan LKPD dalam proses pembelajaran memiliki keuntungan tersendiri untuk mencapai tujuan pembelajaran. LKPD dapat mengarahkan peserta didik untuk belajar mandiri dan mengarahkan peserta didik dalam kegiatan-kegiatan yang sesuai dengan tujuan pembelajaran yang ingin dicapai. Hal tersebut sejalan dengan pendapat Ismail yang menyatakan bahwa dalam pelaksanaan pembelajaran, LKPD mempunyai beberapa kelebihan, yaitu (1) menimbulkan semangat belajar peserta didik; (2) melatih dan mengembangkan cara belajar peserta didik yang mandiri; (3) sebagai sarana belajar yang efektif bagi peserta didik karena berisi langkah-langkah kegiatan yang diuraikan secara sistematis dan praktis. Sementara itu, menurut Depdiknas Lembar Kegiatan Peserta didik memberikan keuntungan bagi guru dan peserta didik. Guru memiliki bahan ajar yang siap digunakan dan memudahkan guru dalam melaksanakan pembelajaran, sedangkan peserta didik akan mendapatkan pengalaman belajar secara mandiri serta belajar memahami dan menjalankan tugas tertulis yang ada di dalam LKS (Depdiknas, 2008).

LKPD yang didesain oleh penulis menggunakan model pembelajaran problem based learning. PBL merupakan suatu model pembelajaran yang melatih peserta didik untuk mengerjakan permasalahan yang autentik yang akan terpusat pada peserta didik dengan maksud agar peserta didik mampu menyusun sendiri pengetahuanya, mengembangkan keterampilan berpikir dan pemecahan masalah, serta mengembangkan kemandirian dan sikap percaya diri. Pada PBL peserta didik dituntut untuk dapat memecahkan masalah yang disajikan dengan cara menggali informasi sebanyak-banyaknya kemudian dianalisis dan dicari penyelesaiannya (Aji dkk., 2017).

Problem Based Learning mendorong peserta didik untuk menemukan pemecahan atas masalah yang diberikan sehingga dapat membantu untuk meningkatkan kemampuan diri peserta didik. Penerapan Problem Based Learning merupakan suatu pendekatan pengajaran yang mempelajari masalah dunia nyata sebagai konteks bagi peserta didik untuk memperoleh pengetahuan serta konsep yang esensi dari mata pelajaran. Model Problem Based Learning adalah model pembelajaran yang merangsang peserta didik untuk berpikir menyelesaikan permasalahan kontekstual. Melalui model Problem Based 
Learning, peserta didik menyusun pengetahuan dengan membangun penalaran sehingga diharapkan dapat memecahkan masalah dengan beragam alternatif solusi serta mengidentifikasi permasalahan yang ada (Hardiyanti dkk., 2017). Model PBL dapat digunakan dalam pembelajaran kimia.

Pembelajaran kimia tidak lepas dari penguasaan konsep, penerapannya dalam menyelesaikan soal-soal atau permasalahan kimia, dan bekerja secara ilmiah. Namun, pembelajaran di dalam kelas saat ini lebih cenderung memfokuskan pada penguasaan konsep dan mengabaikan kemampuan pemecahan masalah sehingga peserta didik tidak terlatih untuk memecahkan masalah yang disajikan. Oleh sebab itu kemampuan peserta didik dalam memecahkan permasalahan yang ada masih sangat rendah. Kemampuan pemecahan masalah sangat dibutuhkan peserta didik dalam pembelajaran kimia. Hal ini karena aktivitas pemecahan masalah dapat membantu peserta didik untuk membangun pengetahuan baru dan membantu dalam pembelajaran kimia. Dalam proses pemecahan masalah dibutuhkan kepercayaan yang tinggi terhadap kemampuan yang kita miliki. Kepercayaan yang tinggi terhadap kemampuan yang dimiliki dinamakan dengan self efficacy.

Self efficacy menjadi sesuatu hal yang perlu dikembangkan, hal ini karena self efficacy yang tinggi dapat menambah keyakinan peserta didik untuk berjuang menggapai apa yang diinginkannya. Menurut Bandura self efficacy dapat memberikan pengaruh yang kuat terhadap hasil belajar peserta didik karena self efficacy mempengaruhi pilihan tugas individu, tenaga, ketekunan, dan prestasi (Hairida, 2017). Salah satu cara untuk mengembangkan self efficacy peserta didik adalah dengan mengembangkan bahan ajar yang ada berupa LKPD, sehingga mampu menuntun peserta didik untuk lebih mandiri dan lebih aktif dalam proses pembelajaran.

Tahap kedua dari Borg and Gall adalah perencanaan yaitu pemilihan format penulisan seperti jenis font, gambar, ilustrasi serta background yang akan digunakan, selain itu juga ada pemilihan materi apa saja yang akan disajikan didalam LKPD sehingga dapat berpengaruh terhadap self efficacy peserta didik. LKPD ini dilengkapi dengan kegiatan pembelajaran yang didesain menggunakan model pembelajaran Problem Based Learning. LKPD yang didesain memuat materi tentang kelarutan dan hasil kali kelarutan.

Tahap ketiga dari penelitian ini adalah pengembangan LKPD yaitu menyusun draft LKPD berbasis Problem Based Learning untuk meningkatkan self efficacy peserta didik pada materi kelarutan dan hasil kali kelarutan. Pada tahap ini didesain bagian-bagian dari LKPD yaitu cover, kata pengantar, bagian pendahuluan meliputi materi prasyarat dan petunjuk penggunaan LKPD, peta konsep, bagian isi meliputi materi dan latihan-latihan soal, serta bagian penutup yang meliputi kegiatan evaluasi dan daftar pustaka.

Pada tahap keempat dari prosedur pengembangan menurut Borg and Gall adalah uji coba terbatas. Pada tahap ini LKPD akan divalidasi oleh dua orang ahli media dan dua orang ahli materi pembelajaran kimia, serta uji kepraktisan kepada tiga orang guru dan 15 orang peserta didik di MA Darul Hikmah Pekanbaru.

Pada tahap kelima dari prosedur pengembangan menurut Borg and Gall adalah revisi produk. Pada tahap ini akan dilakukan revisi berdasarkan saran dan masukan dari ahli media, ahli materi dan guru kimia. Hasil dari revisi akan ditunjukkan kembali ke ahli media, 
ahli materi dan guru kimia sehingga akan didapat LKPD yang valid dan praktis.

\subsection{Kevalidan Lembar Kerja Peserta Didik Berbasis Problem Based Learning untuk Meningkatkan Self Efficacy}

Pada tahap uji coba terbatas LKPD divalidasi oleh ahli media dan ahli materi. Validasi oleh ahli media dan ahli materi ini bertujuan untuk mendapatkan LKPD kimia yang valid dan layak diuji kepraktisannya oleh guru dan peserta didik.

\subsubsection{Validasi oleh Ahli Materi}

Validasi ahli materi bertujuan untuk menilai kelengkapan materi, kebenaran materi, dan sistematika materi. Hal ini sesuai dengan penelitian yang dilakukan oleh Sudaryati dkk. (2017) bahwa aspek yang dinilai pada materi meliputi cakupan materi, akurasi materi, kemutakhiran materi, memacu keingintahuan, dan penerapan pembelajaran berbasis masalah. Adapun validator yang menjadi ahli materi terdiri dari dua orang dosen Pendidikan Kimia UIN SUSKA Riau. Ahli materi diminta untuk mengisi angket penilaian serta memberikan kritik dan saran untuk perbaikan produk. Berdasarkan kritik dan saran dari ahli materi, LKPD berbasis PBL ini perlu direvisi mengenai contoh-contoh soal, rumus yang digunakan, alokasi waktu, penyesuaian gambar dengan materi, penggunaan istilah yang akurat, dan penyajian materi yang lebih mampu meyakinkan peserta didik. Menurut perhitungan angket validasi ahli materi, LKPD kimia berbasis $P B L$ untuk meningkatkan self efficacy peserta didik pada materi kelarutan dan hasil kali kelarutan dikatakan sangat valid dengan persentase penilaian sebesar $94 \%$. LKPD ini kemudian divalidasi oleh ahli media pembelajaran.

\subsubsection{Validasi oleh Ahli Media}

Validasi ahli media bertujuan untuk menilai penyajian LKPD berbasis Problem Based Learning untuk meningkatkan self efficacy peserta didik pada materi kelarutan dan hasil kali kelarutan. Adapun validator yang menjadi ahli media terdiri dari dua orang dosen Pendidikan Kimia UIN SUSKA Riau. Berdasarkan hasil perhitungan angket validasi ahli media, LKPD kimia berbasis PBL untuk meningkatkan self efficacy peserta didik pada materi kelarutan dan hasil kali kelarutan dikatakan sangat valid dengan persentasi penilaian sebesar $98 \%$. Berdasarkan kritik dan saran dari ahli media tersebut, maka dilakukan beberapa revisi sesuai dengan saran validator yaitu mengenai jenis huruf, ukuran huruf, warna huruf, spasi, tanda baca, konsistensi dalam penulisan, desain yang digunakan, kesesuaian background, dan perbaikan kata dengan melengkapi beberapa huruf yang tertinggal. Selanjutnya LKPD ini dinilai oleh guru.

\subsection{Kelayakan Lembar Kerja Peserta Didik Berbasis Problem Based Learning untuk Meningkatkan Self Efficacy}

Setelah LKPD divalidasi oleh ahli media dan ahli materi, LKPD diuji coba oleh guru dan peserta didik guna mengetahui tingkat kepraktisan LKPD yang didesain. Pada langkah ini pengumpulan dan analisis data dapat dilakukan dengan cara wawancara dan angket.

\subsubsection{Praktikalitas LKPD oleh Guru Kimia}

Setelah divalidasi oleh ahli media dan ahli materi, selanjutnya LKPD diuji kepraktisannya kepada guru kimia di MA Darul Hikmah Pekanbaru. Uji coba guru ini dilakukan untuk meyakinkan data dan mengetahui kemenarikan produk secara luas. Responden 
Desain Lembar Kerja Peserta Didik Berbasis Problem Based Learning untuk Meningkatkan Self Efficacy Peserta Didik

pada uji kepraktisan guru ini berjumlah tiga orang. Berdasarkan penilaian angket, hasil rata-rata kepraktisan yang diperoleh sebesar $87 \%$ dan termasuk ke dalam kriteria sangat praktis serta layak diuji cobakan di MA Darul Hikmah Pekanbaru.

Guru menilai bahwa LKPD berbasis Problem Based Learning layak untuk digunakan dalam proses pembelajaran. LKPD berbasis Problem Based Learning ini dapat memberikan dampak positif terhadap peserta didik. Hal ini karena LKPD yang didesain oleh penulis dengan model Problem Based Learning dapat membantu peserta didik selama proses pembelajaran sehingga peserta didik lebih mandiri dalam mengerjakan setiap permasalahan yang diberikan dan terbiasa memecahkan permasalah dengan beragam cara. Menurut Widiyatmoko, Problem Based Learning dapat memberikan kesempatan bagi siswa untuk dapat melatih memecahkan masalah yang disajikan melalui beragam strategi dan taktik pemecahan masalah. Kegiatan belajar dengan diskusi maupun percobaan sederhana dalam kelompok memberikan kesempatan dari masing-masing anggota untuk menyampaikan ide, gagasan, dan strategi pemecahan masalah dalam kelompok sehingga akan muncul gagasan yang terbaik dari setiap usulan yang disampaikan (Widiyatmoko dkk., 2014). Selain itu Giyantono berpendapat bahwa guru dalam proses pembelajaran adalah sebagai pemberi arah atau petunjuk untuk membantu peserta didik jika menemukan kesulitan dalam menyelesaikan masalah. Melalui model pembelajaran Problem Based Learning ini terlihat hubungan peserta didik dengan guru sangat signifikan karena guru tidak dianggap sebagai sosok yang menakutkan tetapi sebagai fasilitator dan mitra untuk berbagi pengalaman atau menyelesaikan masalah sesuai dengan konsep pembelajaran, sehingga pembelajaran dapat berjalan secara maksimal (Giyantono, 2013).

\subsubsection{Respon Peserta Didik Terhadap LKPD}

Sebelum peserta didik memberikan penilaian terhadap LKPD yang didesain oleh peneliti, peserta didik terlebih dulu melakukan penilaian terhadap LKPD yang berasal dari penerbit. Uji coba LKPD yang berasal dari penerbit dilakukan oleh 15 orang peserta didik kelas XI Sains 1 MA Darul Hikmah Pekanbaru. Selanjutnya peserta didik memberikan penilaian terhadap LKPD berbasis $P B L$ untuk meningkatkan self efficacy peserta didik pada materi kelarutan dan hasil kali kelarutan yang didesain oleh peneliti. Penilaian ini dilakukan oleh 15 orang peserta didik kelas XI Sains 2 MA Darul Hikmah Pekanbaru. Hasil rata-rata penilaian peserta didik terhadap LKPD yang berasal dari penerbit (LKPD 1) diperoleh sebesar $74 \%$ dan termasuk dalam kategori praktis serta layak digunakan untuk peserta didik. Hasil rata-rata penilaian peserta didik terhadap LKPD berbasis PBL untuk meningkatkan self efficacy peserta didik pada materi kelarutan dan hasil kali kelarutan (LKPD 2) diperoleh sebesar $81 \%$ termasuk ke dalam kategori sangat praktis dan layak digunakan untuk peserta didik. Perbandingan antara penilaian LKPD yang berasal dari penerbit dengan LKPD yang didesain oleh penulis dapat dilihat pada Gambar 1.

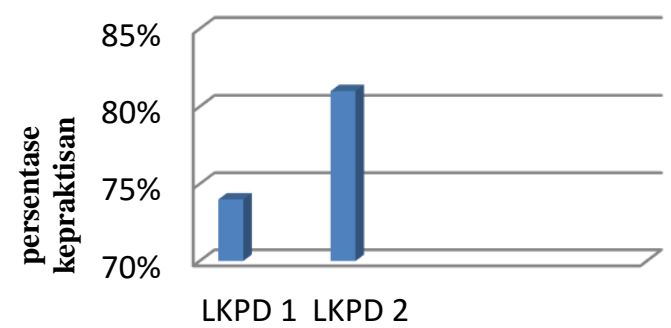
Gambar 1. Perbandingan Respon Peserta Didik antara LKPD Penerbit (LKPD 1) dan LKPD yang Didesain (LKPD 2).


Desain Lembar Kerja Peserta Didik Berbasis Problem Based Learning untuk Meningkatkan Self Efficacy Peserta Didik

Penilaian terhadap LKPD yang berasal dari penerbit mendapatkan hasil yang lebih rendah daripada LKPD yang didesain oleh peneliti. Hal ini karena menurut Astuti dkk., (2018) bahwa kebanyakan LKPD yang beredar di sekolahsekolah masih bersifat umum dan sebagian besar hanya berisi ringkasan-ringkasan materi saja. Materi yang disajikan biasanya bersifat instan tanpa disertai penjelasan detail dan tidak ada petunjuk penggunaan LKPD bagi guru dan siswa. sehingga menyebabkan peserta didik kurang tertarik pada LKPD yang ada dan kurang mengasah kemampuan peserta didik. Selain itu, pengemasan materi yang cenderung kurang dimengerti oleh peserta didik menyebabkan peserta didik hanya menghafal materi tanpa memahami konsep yang ada dan materi tersebut akan mudah dilupakan. Hal ini akan menyebabkan peserta didik ketika diberikan soal yang sedikit bervariasi, peserta didik akan mengalami kebingungan dan kesulitan dalam menyelesaikan soal yang diberikan akibatnya peserta didik akan merasa tidak yakin dengan apa yang dikerjakannya. Sedangkan LKPD yang didesain oleh penulis mendapat hasil yang lebih tinggi, hal ini karena LKPD yang didesain sendiri oleh guru akan meningkatkan ketertarikan siswa karena LKPD tersebut dapat disesuaikan dengan karakteristik siswa, model pembelajaran yang diinginkan dan kondisi lingkungan sekolah.

\subsection{Peningkatan Self Efficacy Peserta Didik}

Self efficacy diperoleh dari hasil pretest yang diberikan kepada peserta didik sebelum menggunakan LKPD yang didesain dan hasil posttest yang diberikan setelah menggunakan LKPD yang didesain berupa lembar angket self efficacy. Angket pretest digunakan untuk mengetahui self efficacy awal peserta didik sebelum menggunakan LKPD yang didesain sedangkan posttest digunakan untuk mengetahui self efficacy peserta didik setelah menggunakan LKPD yang didesain. Lembar angket ini meliputi 3 aspek, yaitu dimensi strenght, magnitude, dan generality. Nilai self efficacy dikatakan tinggi jika mencapai $\geq 61 \%$.

Hasil perhitungan skor menunjukkan 40\% peserta didik mempunyai self efficacy yang sangat tinggi, $47 \%$ peserta didik pada kriteria tinggi, dan $13 \%$ pada kriteria cukup tinggi. Nilai self-efficacy berdasarkan tiap dimensi terdapat pada Gambar 2.

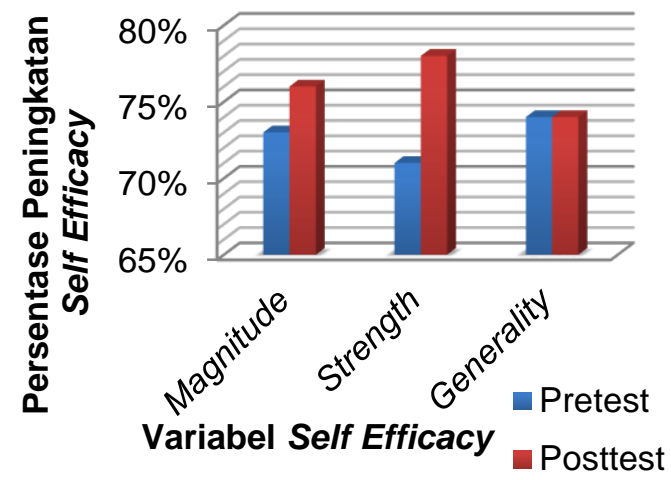

\section{Gambar 2. Grafik Peningkatan Self Efficacy Peserta Didik.}

Self efficacy bila dilihat dari tiap dimensi juga mengalami peningkatan. Dimensi strength memiliki nilai tertinggi setelah digunakan LKPD dalam pembelajaran yaitu sebesar $78 \%$. Hal ini diartikan peserta didik sudah percaya pada kemampuannya dalam meraih tujuan tertentu tetapi masih perlu bimbingan guru karena persentase yang didapat masih dalam kategori tinggi artinya peserta didik belum sepenuhnya percaya pada kemampuannya sendiri. Dimensi generality peserta didik mendapat nilai yang rendah yaitu sebesar 74\%. Persentase tersebut menunjukkan bahwa kepercayaan diri peserta didik akan kemampuannya belum mencakup berbagai situasi dalam mengerjakan latihan atau soal yang diberikan di dalam LKPD. Dimensi magnitude juga sudah sampai pada kriteria tinggi namun dengan nilai yang masih rendah yaitu $76 \%$. Artinya dalam mengerjakan soal dengan tingkat kesulitan yang berbeda, 
Desain Lembar Kerja Peserta Didik Berbasis Problem Based Learning untuk Meningkatkan Self Efficacy Peserta Didik

peserta didik masih ragu akan kemampuannya untuk dapat menyelesaikan latihan soal tersebut sehingga peserta didik lebih memilih soal yang mudah.

Peningkatan self efficacy peserta didik dapat juga dilihat dari gain score. Gain score digunakan untuk mengetahui peningkatan self efficacy peserta didik. Skor yang diperoleh akan diinterpretasikan dengan kriteria $N-g \geq$ 0,7 (tinggi); $0,7>N-g \geq 0,3$ (sedang); dan $N-g<$ 0,3 (rendah). Peningkatan hasil belajar menurut gain score dapat dilihat pada Tabel 3.

Tabel 3. Peningkatan Self Efficacy Peserta Didik dengan Gain Score

\begin{tabular}{lccc}
\hline Nama & $\begin{array}{c}\text { Skor } \\
\text { Pretest }\end{array}$ & $\begin{array}{c}\text { Skor } \\
\text { Posttest }\end{array}$ & N-Gain \\
\hline PD1 & 65 & 65 & 0 \\
PD2 & 99 & 98 & -0.9 \\
PD3 & 98 & 98 & 0 \\
PD4 & 83 & 91 & 6.03 \\
PD5 & 77 & 78 & 0.7 \\
PD6 & 62 & 64 & 1.12 \\
PD7 & 66 & 71 & 3 \\
PD8 & 75 & 73 & -1.3 \\
PD9 & 85 & 85 & 0 \\
PD 10 & 83 & 99 & 12.07 \\
PD 11 & 93 & 91 & -1.7 \\
PD12 & 76 & 78 & 1.38 \\
PD13 & 84 & 85 & 0.76 \\
PD14 & 78 & 99 & 14.89 \\
PD15 & 69 & 81 & 7.52 \\
Jumlah & $\mathbf{1 1 9 3}$ & $\mathbf{1 2 5 6}$ & $\mathbf{0 , 1 3 7 8}$ \\
\hline
\end{tabular}

Hasil perhitungan $N$-gain skor keseluruhan self efficacy adalah 0,1378. Hal ini menunjukan peningkatan self efficacy seluruh peserta didik berada pada kategori rendah. Peningkatan yang sangat rendah ini salah satunya disebabkan karena self efficacy hanya dilihat dari respon peserta didik terhadap LKPD yang didesain bukan menerapkan LKPD yang didesain. Peserta didik diberi kesempatan selama satu jam pelajaran untuk mengerjakan dan menilai LKPD yang didesain oleh penulis. Hasilnya tidak semua latihan yang ada di LKPD terkerjakan, hal ini karena keterbatasan waktu. Peningkatan self efficacy ini hanya dilihat dari pemberian produk bukan penerapan produk dengan model pembelajaran tertentu.

\section{KESIMPULAN}

Berdasarkan hasil penelitian dan pembahasan, maka dapat diambil beberapa simpulan bahwa lembar kerja peserta didik berbasis Problem Based Learning untuk meningkatkan self efficacy peserta didik valid dan layak untuk digunakan. Kevalidan Lembar Kerja Peserta Didik berbasis Problem Based Learning untuk meningkatkan self efficacy peserta didik pada materi kelarutan dan hasil kali kelarutan dapat dilihat dari hasil validasi ahli materi yaitu sebesar $94 \%$ dengan kategori sangat valid dan ahli media yaitu sebesar $98 \%$ dengan kategori sangat valid. Kepraktisan Lembar Kerja Peserta Didik berbasis Problem Based Learning untuk meningkatkan self efficacy peserta didik pada materi kelarutan dan hasil kali kelarutan dapat dilihat dari penilaian guru kimia MA Darul Hikmah Pekanbaru yaitu sebesar $87 \%$ dengan kategori sangat praktis. Respon peserta didik terhadap Lembar Kerja Peserta Didik pada materi kelarutan dan hasil kali kelarutan $\left(K_{s p}\right)$ berbasis Problem Based Learning untuk meningkatkanself efficacy peserta didik pada materi kelarutan dan hasil kali kelarutan didapat dari hasil penilaian angket yaitu sebesar $81 \%$ dengan kategori sangat praktis. Peningkatan self efficacy peserta didik dilihat dari hasil perhitungan $\mathrm{N}$-gain skor keseluruhan self efficacy adalah 0,1378 . Hal ini menunjukan peningkatan self efficacy seluruh peserta didik berada pada kategori rendah. Skor ini hanya dilihat dari respon peserta didik terhadap produk yang didesain. 
Desain Lembar Kerja Peserta Didik Berbasis Problem Based Learning untuk Meningkatkan Self Efficacy Peserta Didik

\section{DAFTAR PUSTAKA}

Agustini, Afifah, E. Q., \& Rudiana. (2017). Pengembangan Modul Berorientasi Contextual Teaching And Learning pada Materi Asam Basa untuk Meningkatkan Self-Efficacy. Unesa Journal Of Chemical Education, 402408.

Aji, S. D., Hudha, M. N., \& Rismawati, A. N. (2017). Pengembangan Modul Pembelajaran Fisika Berbasis Problem Based Learning untuk Meningkatkan Kemampuan Pemecahan Masalah Fisika. Science Education Journal, 3561.

Aprilia, Y., Jalmo, T., \& Marpaung, R. R. (2015). Pengaruh Problem Based Learning Dalam Meningkatkan Self Efficacy Dan Hasil Belajar. The Jurnal Bioterdidik: Wahana Ekspresi Ilmiah, 3, 19-27.

Astuti, S., Danial, M., \& Anwar, M. (2018). Pengembangan LKPD Berbasis PBL (Problem Based Learning) Untuk Meningkatkan Keterampilan Berpikir Kritis Peserta Didik Pada Materi Kesetimbangan Kimia. Jurnal Chemistry Education Review (CER), Pend. Kimia PPs UNM, 90-114.

Depdiknas. (2008). Panduan Pengembangan Bahan Ajar. Jakarta: Direktorat Jenderal Pendidikan Dasar dan Menengah Direktorat Pendidikan Menengah Atas. Retrieved Juni Rabu, 2018, from https://www.academia.edu

Diba, P. F., Wardani, S., \& Sudarmin. (2017). Diba, Pawesti Farrah. (2017). Pengembangan Lembar Kerja Peserta Didik materi Kelarutan Dan Hasil Kali Kelarutan Berbasis Inkuiri Untuk Meningkatkan Keterapilan Generic
Sains Peserta Didik. Journal of Innovative Science Education, 6(2), 1-8.

Evendy, R., Sumarmi, \& Astina, I. K. (2018). Pengembangan Lembar Kerja Peserta Didik Berbasis Kontekstual pada Materi Kearifan dalam Pemanfaatan Sumber Daya Alam. Jurnal Pendidikan: Teori, Penelitian, Dan Pengembangan, 3, 271277.

Giyantono, R. A. (2013). Penerapan Model Pembelajaran Problem Base Learning Pada Mata Diklat Las Kelas X TPM SMK Taman Siswa Surabaya. JPTM, 2, 96102.

Hairida. (2017). Pengembangan Instrumen Untuk Mengukur Self Efficacy Peserta Didik Dalam Pembelajaran Kimia. Edusains, 9, 53-59.

Hardiyanti, P. C., Wardani, S., \& Nurhayati, S. (2017). Keefektifan Model Problem Based Learning Untuk Meningkatkan Keterampilan Proses Sains Peserta Didik. Jurnal Inovasi Pendidikan, 1, 1862-1871.

Ikhasaum, F. (2016). Pengembangan Modul Untuk Meningkatkan Kemampuan Berfikir Kritis Dan Self Efficacy Peserta Didik. Bandar Lampung: Tesis Universitas Lampung., 1-91.

Riduwan. (2007). Skala Pengukuran Variabel Variabel Penelitian. Bandung: Alfabeta.

Sari, E., Syamsurizal, \& Asrial. (2016). Pengembangan Lembar Kegiatan Peserta Didik (LKPD) Berbasis Karakter Pada Mata Pelajaran Kimia SMA. Edu Sains, 5(2), 8-17.

Sudaryati, A., Soeparmi, \& Sarwanto. (2017). Pengembangan Modul Fisika Berbasis Masalah pada Materi Listrik Dinamis 
untuk Meningkatkan Kemampuan Berpikir Kreatif Siswa Kelas X SMA/MA. Jurnal Inkuiri 127-140, 6, 127-140.

Sunaryo, Y. (2017). Pengukuran Self-Efficacy Peserta Didik dalam Pembelajaran Matematika di MTSN 2 Ciamis. Jurnal Teori dan Riset Matematika, 1(2), 3944., 1, 39-44.

Widiyatmoko, Sujiono, \& Ari. (2014). Pengembangan Modul IPA Terpadu Berbasis Problem Based Learning Tema Gerak untuk Meningkatkan Kemampuan Berfikir Kritis Siswa. Unnes Science Education Journal, 685-693. 